\title{
Differentiation and evolutionary relationships in Erythrinus erythrinus (Characiformes, Erythrinidae): occurrence and distribution of B chromosomes
}

\author{
N.F. Martins ${ }^{1}$, M.B. Cioffi ${ }^{1}$, W.P. Troy ${ }^{2}$, J.F. Martinez ${ }^{1}$, O. Moreira-Filho \\ and L.A.C. Bertollo ${ }^{1}$ \\ ${ }^{1}$ Departamento de Genética e Evolução, \\ Centro de Ciências Biológicas e da Saúde, \\ Universidade Federal de São Carlos, São Carlos, SP, Brasil \\ ${ }^{2}$ Departamento de Ciências Biológicas, \\ Universidade do Estado do Mato Grosso, Tangará da Serra, MT, Brasil \\ Corresponding author: L.A.C. Bertollo \\ E-mail: bertollo@ufscar.br
}

Genet. Mol. Res. 13 (3): 7094-7101 (2014)

Received May 29, 2013

Accepted September 20, 2013

Published February 14, 2014

DOI http://dx.doi.org/10.4238/2014.February.14.11

ABSTRACT. Erythrinus erythrinus, a Neotropical fish species of the
Erythrinidae family, has a wide distribution in South America. Previous
cytogenetic analysis showed that this species presents extensive
karyotype diversity, with 4 karyomorphs (A-D) described herein. This
study investigated the karyotypic structure of 2 new populations of $E$.
erythrinus from the Brazilian Pantanal region, in order to improve
the knowledge of the chromosomal diversity in this species. Both
populations showed typical characteristics of karyomorph A, with $2 \mathrm{n}=$
54 chromosomes $(6 \mathrm{~m}+2 \mathrm{st}+46 \mathrm{a})$, without differentiation between males
and females. In addition, identical supernumerary B chromosomes,
appearing as double-minute chromosomes, were also found in both
populations. These findings suggest the presence of mitotic instability
in view of their high intra- and inter-individual numerical variation. The 
presence of these chromosomes is likely a basal characteristic for this group, since the same kind of Bs also occurs in some other populations and karyomorphs of E. erythrinus. As such, they are important markers of biodiversity found in this nominal species, which probably corresponds to a species complex.

Key words: Fish; Species complex; Chromosomal diversity; Supernumerary chromosomes

\section{INTRODUCTION}

Erythrinidae is a small Neotropical fish family, with only 3 recognized genera, i.e., Hoplias, Hoplerytrinus, and Erythrinus. The genus Erythrinus includes only 2 nominal species: Erythrinus erythrinus, which has a wide distribution in South America, and Erythrinus kessleri with a restricted distribution (Oyakawa, 2003). Cytogenetic studies conducted on E. erythrinus indicate that this species is probably a species complex, with 4 karyomorphs (A-D) differing both in chromosomal number and morphology, as well as in the occurrence of heteromorphic sex chromosomes (reviewed in Cioffi et al., 2012). Karyomorph A presents $2 \mathrm{n}=54$ chromosomes [ 6 metacentrics (m) +2 subtelocentrics (st) +46 acrocentrics (a)] in males and females, without submetacentric (sm) chromosomes and heteromorphic sex chromosomes. The other 3 karyomorphs (B-D) share a multiple $\mathrm{X}_{1} \mathrm{X}_{1} \mathrm{X}_{2} \mathrm{X}_{2} /$ $\mathrm{X}_{1} \mathrm{X}_{2} \mathrm{Y}$ sex chromosome system, but have different karyotypic formulas. Karyomorph B has $2 \mathrm{n}=54$ chromosomes in females and $2 \mathrm{n}=53$ chromosomes in males $(+6 \mathrm{~m}+2 \mathrm{st}+46 \mathrm{a} ; \hat{\delta} 7 \mathrm{~m}+2 \mathrm{st}+44 \mathrm{a})$; karyomorph $\mathrm{C}$ has $2 \mathrm{n}=52$ chromosomes in females and $2 \mathrm{n}=51$ chromosomes in males $(q 6 \mathrm{~m}+$ $\left.2 \mathrm{sm}+6 \mathrm{st}+38 \mathrm{a} ;{ }^{\lambda} 7 \mathrm{~m}+2 \mathrm{sm}+6 \mathrm{st}+36 \mathrm{a}\right)$; and karyomorph $\mathrm{D}$ has $2 \mathrm{n}=52$ chromosomes in females and $2 \mathrm{n}=51$ chromosomes in males ( $4 \mathrm{~m}+2 \mathrm{sm}+2 \mathrm{st}+44 \mathrm{a} ; \widehat{\partial} 5 \mathrm{~m}+2 \mathrm{sm}+2 \mathrm{st}+42 \mathrm{a})$.

Small supernumerary B chromosomes, morphologically similar to "double-minute chromosomes", have already been found in some populations of E. erythrinus (Bertollo et al., 2004). Since their discovery in the last century (Wilson, 1907), supernumerary chromosomes have been the subject of many investigations in respect to their origin and biological significance (Camacho et al., 2000). Although occurring in several biological groups (Jones and Rees, 1982), they are dispensable elements usually not following the Mendelian inheritance pattern, with an irregular segregation during meiosis (Jones and Rees, 1982; Buekeboom, 1994; Camacho et al., 2000). B chromosomes commonly have smaller sizes and distinct morphologies in relation to the standard chromosomes (A) of the karyotype, and their evolutionary process is usually associated with the occurrence of heterochromatinization and accumulation of repetitive DNAs (Camacho et al., 2000).

In this study, the karyotype structure of new populations of E. erythrinus, which have not been yet investigated, from 2 Brazilian regions were analyzed. The main objective of this study is to improve the knowledge of chromosomal diversity and geographic distribution of the karyomorphs in this fish species. The results indicated broader participation of B chromosomes in the karyotype diversification of E. erythrinus and reinforced that this nominal species represents, in fact, an assemblage of species with unresolved taxonomy.

\section{MATERIAL AND METHODS}

\section{Specimens}

Forty specimens of E. erythrinus from 2 Brazilian sites were analyzed. In all, 16 fe- 
males and 14 males were from the Barão de Melgaço region (16 $\left.16^{\prime} 16.67^{\prime \prime} \mathrm{S}, 55^{\circ} 57^{\prime} 26.28^{\prime \prime} \mathrm{W}\right)$ and 7 females and 3 males were from the Poconé region $\left(16^{\circ} 15^{\prime} 48.32^{\prime \prime} \mathrm{S} ; 56^{\circ} 37^{\prime} 48.64 " \mathrm{~W}\right.$; Figure 1). Both sites are situated in the Pantanal of the Mato Grosso State, which comprises a mostly flooded extensive area of $250,000 \mathrm{~km}^{2}$ in the Midwest of Brazil.

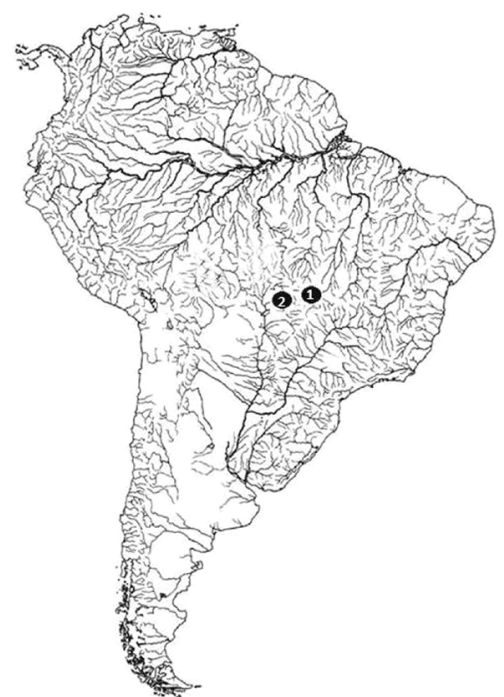

Figure 1. Collection sites of two Brazilian Erythrinus erythrinus samples analyzed in this study. 1 = Poconé region; 2 = Barão de Melgaço region.

\section{Mitotic chromosome preparations}

The specimens were first treated with a $0.005 \%$ colchicine solution $(1 \mathrm{~mL}$ solution $/ 100$ g body weight) for a period of 40-50 min. Next, they were anesthetized, and their anterior kidney was removed; the tissues were dissociated to obtain a homogeneous suspension of cells. The metaphase chromosomes were obtained according to the conventional air-drying method (Bertollo et al., 1978). In brief, cells were treated with a hypotonic $\mathrm{KCl}$ solution $(0.075 \mathrm{M})$ for $20 \mathrm{~min}$ at $36^{\circ} \mathrm{C}$ and fixed 3 times in methyl alcohol ( 3 parts): glacial acetic acid (1 part). The metaphase plates were analyzed by light microscopy (Olympus BX50), and images were captured using the CoolSNAPPro software (Media Cybernetics). At least 30 metaphases from each specimen were analyzed. The chromosomes were classified as m, sm, st, and a, according to the arm ratio (Levan et al., 1964).

\section{RESULTS}

Both populations showed the same karyotype characteristics, i.e., $2 \mathrm{n}=54$ chromosomes ( $6 \mathrm{~m}$ $+2 s t+46 a)$ without differentiation between males and females (Figure 2). Additionally, they also showed supernumerary B chromosomes, which usually appeared like double-minute chromosomes and stained less than the standard chromosomes. There were $0-6 \mathrm{~B}$ chromosomes per cell, considering the sample of 521 metaphases analyzed. Cells not carrying Bs were the most frequent (38.9\%), followed by cells carrying $1 \mathrm{~B}(20.9 \%)$ and 2Bs (20.5\%). Cells carrying 3 to 6 Bs had lower frequency, approximately, $19.7 \%$ of the sample. Accordingly, cells with 1 or 2 Bs corresponded to $41.4 \%$ of the total sample analyzed, unlike cells carrying a larger number of Bs (Figures 3 and 4). 


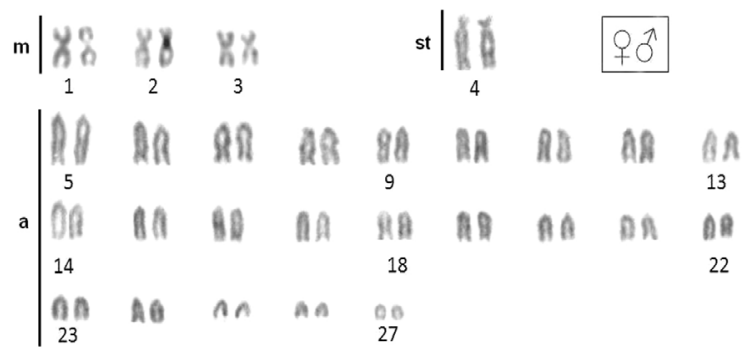

mi I $=$.

Figure 2. Male and female karyotypes for both Erythrinus erythrinus populations analyzed, showing $2 \mathrm{n}=54$ chromosomes $(6 \mathrm{~m}+2 \mathrm{st}+46 \mathrm{a})$ and two supernumerary B chromosomes. $\mathrm{m}=$ metacentric; $\mathrm{st}=$ subtelocentric; $\mathrm{a}=$ acrocentric; $\mathrm{mi}=\mathrm{B}$ chromosomes. $\mathrm{Bar}=5 \mu \mathrm{m}$.
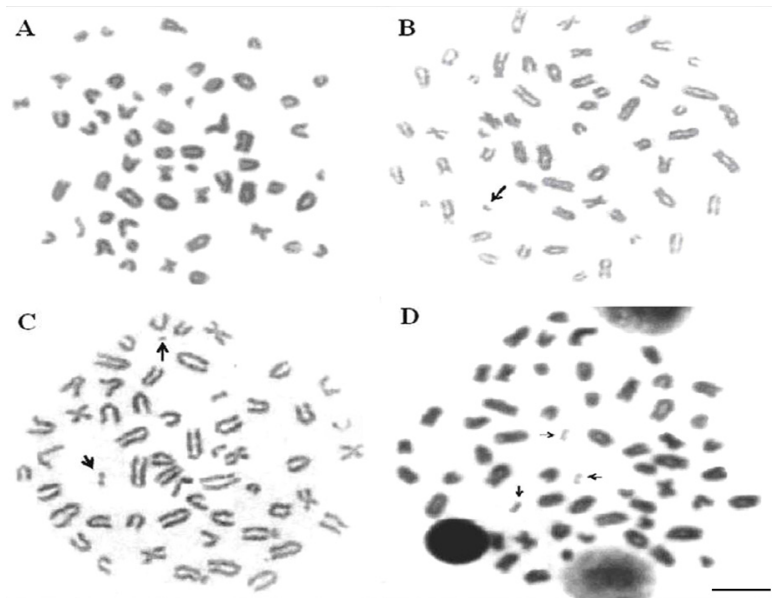

Figure 3. Metaphase chromosomes representative of both Erythrinus erythrinus populations investigated, showing no B chromosomes (A), one B chromosome (B), two B chromosomes (C), and three B chromosomes (D) indicated by arrows. Bar $=5 \mu \mathrm{m}$.

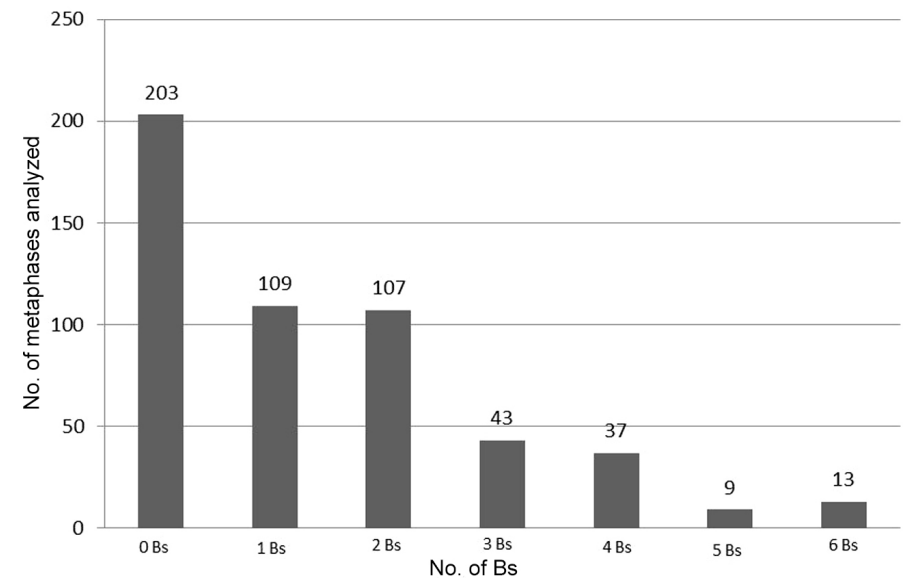

Figure 4. Frequency of B chromosomes found in the two populations of Erythrinus erythrinus. Note the higher frequency of 1-2 Bs/cell, the intermediate frequency of 3-4 Bs/cell, and the lower frequency of 5-6 Bs/cell. 


\section{DISCUSSION}

The 2 new populations of E. erythrinus showed the same karyotype, highlighting the typical chromosomal features of karyomorph A (Bertollo et al., 2004). These data showed that this karyomorph has a wider distribution than the other karyomorphs. In fact, while karyomorph A was already found in the Southeast and Midwest Brazilian regions and Northern Argentina, the karyomorphs B-D were only more punctually located (Bertollo et al., 2004 and the present study).

Micro-B chromosomes were also found in both populations. However, these chromosomes are not exclusive to the investigated populations, since they are also found in some other populations of karyomorphs A and B. Previous studies have indicated that karyomorph A might represent the basal condition in E. erythrinus, from which the other karyomorphs would have diversified (Bertollo et al., 2004). Among these, karyomorph B shows a greater proximity to karyomorph A, retaining the same number of chromosomes in females $(2 n=54)$, but reducing it in males $(2 n=53)$ due the differentiation of a multiple $\mathrm{X}_{1} \mathrm{X}_{1} \mathrm{X}_{2} \mathrm{X}_{2} / \mathrm{X}_{1} \mathrm{X}_{2} \mathrm{Y}$ sex chromosome system (Bertollo et al., 2004). The occurrence of the same type of Bs among different karyomorphs and populations from different geographic regions is indicative of the ancestry of these chromosomes. Therefore, they might represent a basal characteristic in E. erythrinus and are now found among some populations of different karyomorphs, with or without differentiated sex chromosomes (Figure 5). In fact, one of the main properties of B chromosomes is the non-universality, i.e., their independent occurrence among some individuals of some populations of a species, following a particular evolutionary pathway (Camacho et al., 2000). In this context, populations of different karyomorphs, in addition to those already investigated, are expected to present these additional chromosomes, thereby raising questions regarding their possible roles.

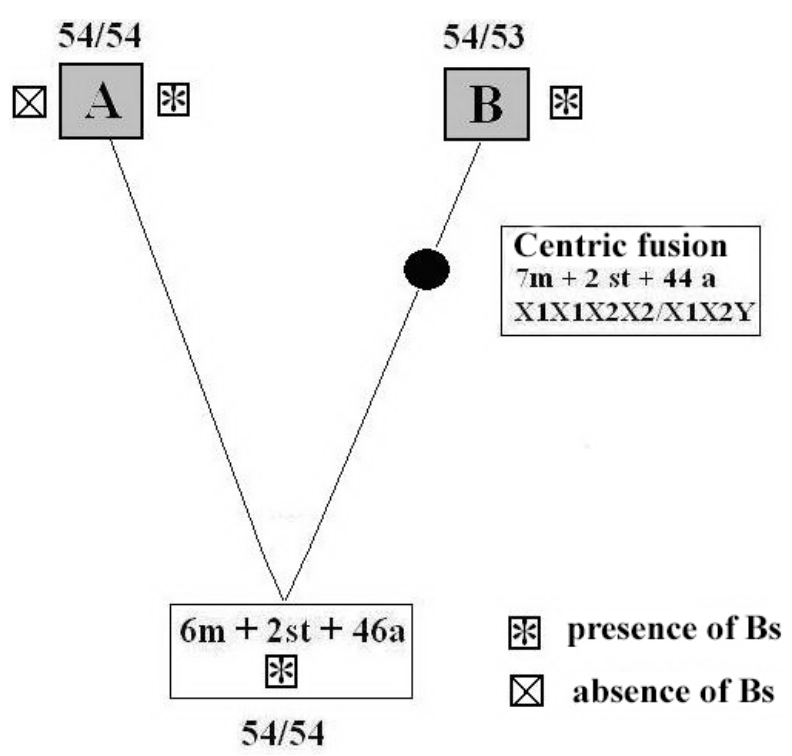

Figure 5. Evolutionary differentiation of Erythrinus erythrinus populations from karyomorphs A $(2 \mathrm{n}=54$ chromosomes, without differentiated sex chromosomes $)$ and $\mathrm{B}\left(2 \mathrm{n}=54\right.$ chromosomes in females, $\mathrm{X}_{1} \mathrm{X}_{1} \mathrm{X}_{2} \mathrm{X}_{2}$ and $2 \mathrm{n}=53$ chromosomes in males, $\mathrm{X}_{1} \mathrm{X}_{2} \mathrm{Y}$ ), based on their chromosomal characteristics. Note the occurrence of micro-B chromosomes shared by some populations of the karyomorphs A and B. 
In general, the absence of phenotypic traits correlated with the presence of Bs suggests that they are genomic parasites without benefits for their carriers (Camacho et al., 2000). However, some specific situations indicate probable roles performed by these chromosomes, as in the cichlid species from Lake Victoria (Africa), where a female-specific B chromosome carries several genes encoding proteins, highlighting its possible functional effect on female sex determination (Yoshida et al., 2011). Likewise, in Chilomycterus spinosus (Tetraodontiformes), a B chromosome is restricted to males and behaves as a univalent during meiosis, also suggesting its correlation with sex differentiation in this species (Noleto et al., 2012). Similarly, in Astyanax scabripinnis (Characiformes), B chromosomes have a major occurrence among females, besides their altitudinal variation in frequency (Néo et al., 2000a,b), suggesting possible adaptive effects.

B chromosomes are known to occur in several fish species. According to the revision study of Carvalho et al. (2008), supernumerary chromosomes were recorded for 61 fish species, predominantly belonging to distinct families of the orders Characiformes and Siluriformes. These chromosomes have different morphologies and sizes, ranging from very small like in Prochilodus (Pauls and Bertollo, 1983) and Moenkhausia (Foresti et al., 1989), medium sized as in Rhamdia (Fenocchio and Bertollo, 1990), to the largest ones of the complement as in Astyanax (Salvador and Moreira-Filho, 1992; Maistro et al., 1992). In some species, there is structural and functional evidence that B chromosomes have an intraspecific origin, for example, the large isochromosome found in A. scabripinnis (Vicente et al., 1996; Mestriner et al., 2000; Vicari et al., 2011). Bs also seems to have an intraspecific origin in the species Prochilodus lineatus considering the chromosomal markers derived from repetitive DNA (de Jesus et al., 2003; Artoni et al., 2006). At present, information concerning the intra- or interspecific origin of supernumerary chromosomes found in E. erythrinus is lacking. However, in view of their characteristics, it is likely that they could have arisen from chromosomal rearrangements occurred during the evolutionary history of this species.

Mitotic instability is another noteworthy attribute of most B chromosomes (Jones and Rees, 1982). However, there are also several records indicating stable mitotic behavior for these chromosomes, as in A. scabripinnis where a macro-B chromosome is permanently found in the cells of the carriers (Moreira-Filho et al., 2004). In addition, in P. lineatus, unstable B chromosomes have become mitotically stable over time. Populations of this species usually have from 0 to 7 small B chromosomes (Pauls and Bertollo, 1983; Oliveira et al., 1997; Cavallaro et al., 2000; Artoni et al., 2006), which may, however, reach up to 9 in experimental crosses (Voltolin et al., 2011). In a natural population of $P$. lineatus, the frequency of B chromosomes doubled over few years. Concomitantly, the instability of these chromosomes had a marked decrease, suggesting that the mitotic stabilization might be the reason why unstable B chromosomes may become neutralized (Cavallaro et al., 2000). Indeed, this neutralization was also supported by the value of their transmission rate $(\mathrm{KB} \approx 0.5)$, indicating a Mendelian mode of inheritance (Oliveira et al., 1997). The numerical variation of Bs in E. erythrinus shows that they are also mitotically unstable in this species. In fact, variations occurred between not only the different specimens analyzed, but also the different metaphases of the same specimen.

The particular chromosomal characteristics of the karyomorphs of E. erythrinus and their geographic distributions reinforce that this nominal species probably corresponds to a species complex. Indeed, its biodiversity is evidenced by the distinct chromosomal rearrangements that are a characteristic of each karyomorph (Bertollo et al., 2004; Cioffi et al., 2010), 
including the origin of a multiple sex chromosome system and the supernumerary chromosomes presently found in some populations.

\section{ACKNOWLEDGMENTS}

Research supported by FAPESP (Fundação de Amparo à Pesquisa do Estado de São Paulo), CNPq (Conselho Nacional de Desenvolvimento Científico e Tecnológico), CAPES (Coordenação de Aperfeiçoamento de Pessoal do Ensino Superior), and FAPEMAT (Fundação de Amparo à Pesquisa do Estado do Mato Grosso). The authors also thank IBAMA for the permission for fish sampling (\#10538-1).

\section{REFERENCES}

Artoni RF, Vicari MR, Endler AL, Cavallaro ZI, et al. (2006). Banding pattern of A and B chromosomes of Prochilodus lineatus (Characiformes, Prochilodontidae), with comments on B chromosomes evolution. Genetica 127: 277-284.

Bertollo LAC, Takahashi CS and Moreira-Filho O (1978). Cytotaxonomic considerations on Hoplias lacerdae (Pisces, Erythrinidae). Braz. J. Genet. 1: 103-120.

Bertollo LA, Oliveira C, Molina WF, Margarido VP, et al. (2004). Chromosome evolution in the erythrinid fish, Erythrinus erythrinus (Teleostei: Characiformes). Heredity 93: 228-233.

Buekeboom LW (1994). Bewildering Bs: an impression of the 1st B-Chromosome Conference. Heredity 73: 328-336.

Camacho JP, Sharbel TF and Beukeboom LW (2000). B-chromosome evolution. Philos. Trans. R. Soc. Lond B Biol. Sci. 355: 163-178.

Carvalho RA, Martins-Santos IC and Dias AL (2008). B chromosomes: an update about their occurrence in freshwater Neotropical fishes (Teleostei). J. Fish Biol. 72: 1907-1932.

Cavallaro ZI, Bertollo LA, Perfectti F and Camacho JP (2000). Frequency increase and mitotic stabilization of a B chromosome in the fish Prochilodus lineatus. Chromosome Res. 8: 627-634.

Cioffi MB, Martins C and Bertollo LA (2010). Chromosome spreading of associated transposable elements and ribosomal DNA in the fish Erythrinus erythrinus. Implications for genome change and karyoevolution in fish. BMC Evol. Biol. 10: 271 .

Cioffi MB, Moreira-Filho O, Almeida-Toledo LF and Bertollo LA (2012). The contrasting role of heterochromatin in the differentiation of sex chromosomes: an overview from Neotropical fishes. J. Fish. Biol. 80: 2125-2139.

de Jesus CM, Pedro MG Jr, Valentini SR and Moreira-Filho O (2003). Molecular characterization and chromosomal localization of two families of satellite DNA in Prochilodus lineatus (Pisces, Prochilodontidae), a species with B chromosomes. Genetica 118: 25-32.

Fenocchio AS and Bertollo LAC (1990). Supernumerary chromosomes in a Rhamdia hilarii population (Pisces, Pimelodidae). Genetica 81: 193-198.

Foresti F, Almeida Toledo LF and Toledo Filho SA (1989). Supernumerary chromosome system, C-banding pattern characterization and multiple nucleolus organizer regions in Moenkhausia sanctaefilomenae (Pisces, Characidae). Genetica 79: 107-114.

Jones RN and Rees H (1982). B Chromosomes. Academic Press, London.

Levan A, Fredga K and Sandberg AA (1964). Nomenclature for centromeric position on chromosomes. Hereditas 52: 201-220.

Maistro EL, Foresti F, Oliveira C and Almeida-Toledo LF (1992). Occurrence of macro B chromosomes in Astyanax scabripinnis paranae (Pisces, Characifomres, Characidae). Genetica 87: 101-106.

Mestriner CA, Galetti PM Jr, Valentini SR, Ruiz IR, et al. (2000). Structural and functional evidence that a B chromosome in the characid fish Astyanax scabripinnis is an isochromosome. Heredity 85 (Pt 1): 1-9.

Moreira-Filho O, Galetti PM Jr and Bertollo LA (2004). B chromosomes in the fish Astyanax scabripinnis (Characidae, Tetragonopterinae): an overview in natural populations. Cytogenet. Genome Res. 106: 230-234.

Néo DM, Filho OM and Camacho JP (2000a). Altitudinal variation for B chromosome frequency in the characid fish Astyanax scabripinnis. Heredity 85 (Pt 2): 136-141.

Néo DM, Bertollo LA and Filho OM (2000b). Morphological differentiation and possible origin of B chromosomes in natural Brazilian population of Astyanax scabripinnis (Pisces, Characidae). Genetica 108: 211-215.

Noleto RB, Vicari MR, Cestari MM and Artoni RF (2012). Variable B chromosomes frequencies between males and 
females of two species of pufferfishes (Tetraodontiformes). Rev. Fish Biol. Fish. 22: 343-349.

Oliveira C, Saboya SMR, Foresti F, Senhorini JÁ, et al. (1997). Increased B chromosome frequency and absence of drive in the fish Prochiodus lineatus. Heredity 79: 473-476.

Oyakawa OT (2003). Family Erythrinidae. In: Check List of the Freshwater Fishes of South and Central America (Reis RE, Kullander SO and Ferraris Jr CJ, eds.). Edipucrs, Porto Alegre, 238-240.

Pauls E and Bertollo LAC (1983). Evidence for a system of supernumerary chromosomes in Prochilodus scrofa Steindachner, 1881 (Pisces, Prochilodontidae). Caryologia 36: 207-314.

Salvador LB and Moreira-Filho O (1992). B chromosomes in Astyanax scabripinnis (Pisces, Characidae). Heredity 69: $50-56$.

Vicari MR, de Mello Pistune HF, Castro JP, de Almeida MC, et al. (2011). New insights on the origin of B chromosomes in Astyanax scabripinnis obtained by chromosome painting and FISH. Genetica 139: 1073-1081.

Vicente VE, Moreira-Filho O and Camacho JP (1996). Sex-ratio distortion associated with the presence of a B chromosome in Astyanax scabripinnis (Teleostei, Characidae). Cytogenet. Cell Genet. 74: 70-75.

Voltolin TA, Senhorini JA, Foresti F, Bortolozzi J, et al. (2011). Intraspecific crosses resulting in the first occurrence of eight and nine B chromosomes in Prochilodus lineatus (Characiformes, Prochilodontidae). Genet. Mol. Biol. 34: 220-224.

Wilson EB (1907). The supernumerary chromosomes of Hemiptera. Science 26: 870-871.

Yoshida K, Terai Y, Mizoiri S, Aibara M, et al. (2011). B chromosomes have a functional effect on female sex determination in Lake Victoria cichlid fishes. PLoS Genet 7: e1002203. 